\title{
Cryptococcus lupi sp. nov., an Antarctic Basidioblastomycete
}

\author{
SIAVASH BAHARAEEN AND HELEN S. VISHNIAC \\ Department of Microbiology, Oklahoma State University, Stillwater, Oklahoma 74074
}

\begin{abstract}
Cryptococcus lupi sp. nov. was isolated from soil samples from the Dry Valleys of South Victoria Land, Antarctica. The guanine-plus-cytosine content (53.3 mol\%) of C. lupi deoxyribonucleic acid differs by more than $1.5 \mathrm{~mol} \%$ from the guanine-plus-cytosine contents of biotypes originally described under the name Cryptococcus vishniacii. The type strain of $C$. lupi (MYSW 202Y252 = ATCC 44529) differs phenotypically from the type strain of $C$. vishniacii in that it assimilates cellobiose, methyl- $\alpha$-D-glucoside, and salicin and fails to assimilate $\gamma$ amino butyric acid, gluconate, 2-ketogluconate, 5-ketogluconate, L-rhamnose, and succinate; it also differs by having a higher maximum growth temperature and in its cell size and ratio of cell width to length.
\end{abstract}

The only heterotrophs demonstrably indigenous to the barren (lichen-free) sites of the Dry Valleys of Antarctica are yeasts belonging to the Cryptococcus vishniacii complex. Determinations of the guanine-plus-cytosine $(\mathrm{G}+\mathrm{C})$ contents of the deoxyribonucleic acids (DNAs) of the organisms in this complex allowed the segregation of biotypes 12 and 13 as a new species, for which we propose the name Cryptococcus lupi (lu'pi. L. noun lupus wolf; L. gen. noun lupi of a wolf; in honor of Wolf Vladimir Vishniac, 19221973, who collected the soil samples from which these yeasts were isolated).

\section{MATERIALS AND METHODS}

The methods of collection, isolation, and characterization of the yeasts have been described elsewhere $(14,15)$. For additional physiological studies we used the following methods.

Cycloheximide resistance was determined by visual estimation of growth on GPYPi $(0.5 \%$ glucose, $0.5 \%$ peptone, $0.3 \%$ yeast extract, $10 \mathrm{mM}$ potassium phosphate buffer, $\mathrm{pH}$ 6.86) agar to which an appropriate amount of cycloheximide stock solution in $95 \%$ ethanol was added when the agar was still hot from autoclaving. No growth during the 19-day observation period was referred to as suppressed, and growth delay was referred to as inhibition.

The method of determining the temperature limits for growth has been described previously $(14,15)$. The temperature for optimum growth was determined by transferring to fresh GPYPi medium a volume of exponentially growing (at $10^{\circ} \mathrm{C}$ ) cells sufficient to yield an optical density at $650 \mathrm{~nm}$ of 0.2 . These secondary cultures were grown at the desired temperatures on a refrigerated Gyrotory water bath shaker (New Brunswick Scientific Co.) at $190 \mathrm{rpm}$. At appropriate intervals, samples $(1 \mathrm{ml})$ were removed without stopping the shaker for determinations of the change in optical density (Bausch \& Lomb Spectronic 70 spectrophotometer) with time.

The other methods used in the morphological studies have been described previously (1a).
Coenzyme $\mathrm{Q}(\mathrm{CoQ})$ was isolated by the method of Yamada and Kondo (16). The CoQ type was identified by cochromatography with standard CoQs (Sigma Chemical Co.) in a reverse-phase system, using petrolatum-coated (2.5\% in toluene) Whatman no. 1 paper and $N, N$-dimethyl formamide $(97: 3)$ in water as the solvent system.

Reactions to diazonium blue B were determined by applying freshly prepared, chilled diazonium reagent to 3-week-old colonies on GPYPi agar, as described by van der Walt and Hopsu-Havu (13). A positive reaction was recorded when the colonies developed a dark red color within 1 to $2 \mathrm{~min}$ at room temperature.

DNA extraction and purification were accomplished by a combination of the procedures of Marmur $(8)$ and Bernardi et al. (3), as described by Price et al. (10). DNA purification was repeated if the preparation deviated more than $0.05 \mathrm{u}$ from a ratio of absorbance at $260 \mathrm{~nm}$ to absorbance at $280 \mathrm{~nm}$ of 1.86 and a ratio of absorbance at $230 \mathrm{~nm}$ to absorbance at $260 \mathrm{~nm}$ of 0.50 (9). The $\mathrm{G}+\mathrm{C}$ content of the nuclear DNA was calculated from three separate determinations of buoyant density in cesium chloride (optical grade; Sigma Chemical Co.) $(11,12)$ in a Beckman model L5-50 preparative ultracentrifuge equipped with a Prep UV scanner (Beckman) and an An-F analytical rotor modified for use in the L5-50 ultracentrifuge (Beckman). Micrococcus luteus (kindly provided by E. A. Grula, Department of Microbiology, Oklahoma State University) DNA was used as a reference; this DNA had a buoyant density of $1.731 \mathrm{~g} / \mathrm{ml}$ compared with DNA from Escherichia coli K-12 strain NX-185 (plasmid free; obtained from A. Rashtchian, Department of Medical Microbiology, University of Nebraska Medical Center), the density of which was calculated to be $1.710 \mathrm{~g} / \mathrm{ml}$ from the formula given in the Prep $U V$ Scanner Instruction Manual (2).

\section{RESULTS}

Latin diagnosis of Cryptococcus lupi sp. nov. Coloniae in agaro colore cremeo, aut politae et mucosae aut asperae et durae; in mediis liquidiis difficiliter crescit, pelliculam haud, annulum exi- 


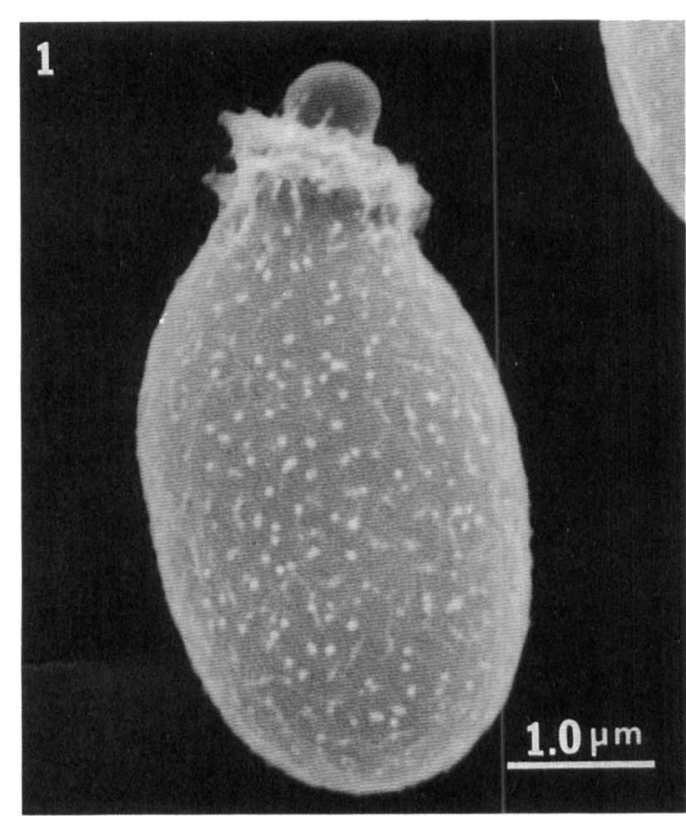

FIG. 1. Scanning electron micrograph of $C$. lupi strain 202Y252 multiparous budding cell showing the characteristic frayed collar of basidioblastomycetes. The capsule, collapsed as a result of critical-point drying, appears as nodules and lines on the surface.

gue, et sedimentum lente formans. Cellulae crescentes forma ova vel lagonae, ca. $5 \times 6 \mu \mathrm{m}$, cum capsulis exiguis, e situ cicatricis natalis iterumque iterumque generatae. Parietes typici Basidioblastomycetium. Nec pseudomycelium nec mycelium formatur. Non generant sed per modo blastico asexuali, calore minus $4^{\circ} \mathrm{C}$ usque ad $25^{\circ} \mathrm{C}$.

Fermentatio nulla. Assimilat L-arabinosum, cellobiosum, acidum citricum, fructosum, glucosum, acidum D-glucuronicum, acidum D-glutamicum (variabile), maltosum, mannosum, melizitosum, methyl- $\alpha$-D-glucosidum, raffinosum, salicinum, sucrosum, trehalosum, D-xylosumque. Amylosum formatum est. Crescit cum nitrato; crescit sine vitaminis. Gelatinum et urea non finduntur. $\mathrm{CoQ}_{9}$ continens; diazonium blue $\mathrm{B}$ respondens. $\mathrm{G}+\mathrm{C}$ ca. $53.3 \mathrm{~mol} \%$.

Standard description of Cryptococcus lupi sp. nov. This species is typified by isolate MYSW 202Y252, which was isolated from coarse, weathered dolerite gravel from the north flank of Mount Baldr (South Victoria Land, Antarctica) at 6,220 feet $(1,896 \mathrm{~m})$. The species comprises isolates originally described as $C$. vishniacii biotypes 12 (the type isolate and, from other Dry Valley sites, isolates 302Y253, 303 Y267, and 306 Y 250 ) and 13 (isolates 202 Y 375 and 303Y368)
(14). The type strain (MYSW 202Y252) has been deposited in the American Type Culture Collection, Rockville, Md., as ATCC 44529.

Colonies on glucose-peptone-yeast extract agar are cream colored, entire, glistening, and somewhat mucoid; on malt extract agar, they are tough and granular. Growth in liquid media is limited unless agitation and aeration are provided; in tubes, a scanty annulus (no pellicle) and slowly produced sediment provide the only evidence of growth. Exponentially growing cultures may produce very small amounts of rudimentary pseudomycelium; pseudomycelium and mycelium are not formed. Sexual reproduction is unknown.

Cells in exponentially growing GPYPi cultures are ovoid to flask shaped, averaging 5.06 (standard deviation, \pm 0.71 ) by 6.11 (standard deviation, \pm 0.71$) \mu \mathrm{m}$, with a ratio of width to length of $0.83 \pm 0.07$. Cells are thinly encapsulated (Fig. 1). Budding is monopolar and repetitive through the birthscar site (1); primary buds are holoblastic (Fig. 2), and secondary buds are enteroblastic, with the septum formed at the level of the characteristic frayed collar of basidioblastomycetes (Fig. 3).

Fermentation does not occur.

Carbon compounds assimilated: L-arabinose, cellobiose, citrate, fructose, glucose, D-glucuronate, L-glutamate (variable response), maltose, mannose, melezitose, methyl- $\alpha$-D-glucoside, raffinose, salicin, sucrose, tartrate (variable response), trehalose, and D-xylose. Amylose is produced during growth on L-arabinose, glucose, or xylose. The following compounds were not assimilated as sole sources of carbon and energy (arbutin and methanol were not tested): acetate, amino acids other than glutamate (L-alanine, $\gamma$-amino butyrate, L-arginine, L-aspartate, glycine, L-isoleucine, Llysine, L-methionine, L-ornithine, L-phenylalanine, L-proline, and L-valine), D-arabinose, Darabitol, L-arabitol, butyrate, decane, erythritol, ethanol, D-fucose, fumarate, galactitol, D-galactose, D-glucitol, D- $\delta$-gluconolactone, glycerol, myo-inositol, inulin, 2-ketogluconate, 5-ketogluconate, DL-lactate, lactose, L-malate, D-mannitol, melibiose, L-rhamnose, ribitol, D-ribose, L-sorbose, starch, succinate, and xylitol.

Nitrogen sources utilized: $\mathrm{NH}_{4} \mathrm{Cl}, \mathrm{KNO}_{3}$, Lamino acids ( $\mathrm{L}$-alanine, $\mathrm{L}$-arginine, $\mathrm{L}$-aspartate, L-glutamate, glycine, L-histidine, L-isoleucine, L-lysine, L-methionine, L-ornithine, L-phenylalanine, L-proline, and L-valine). Not utilized: Dalanine, creatinine, cytosine, ethylamine, nicotinic acid, thiamine, thymine, and uracil.

Gelatin and urea are not hydrolyzed.

Externally supplied vitamins are not required.

Growth occurs from less than 4 to $25^{\circ} \mathrm{C}$; optimal growth is at $17^{\circ} \mathrm{C}$.

Growth is inhibited by $0.05 \mu \mathrm{g}$ of cyclohexi- 

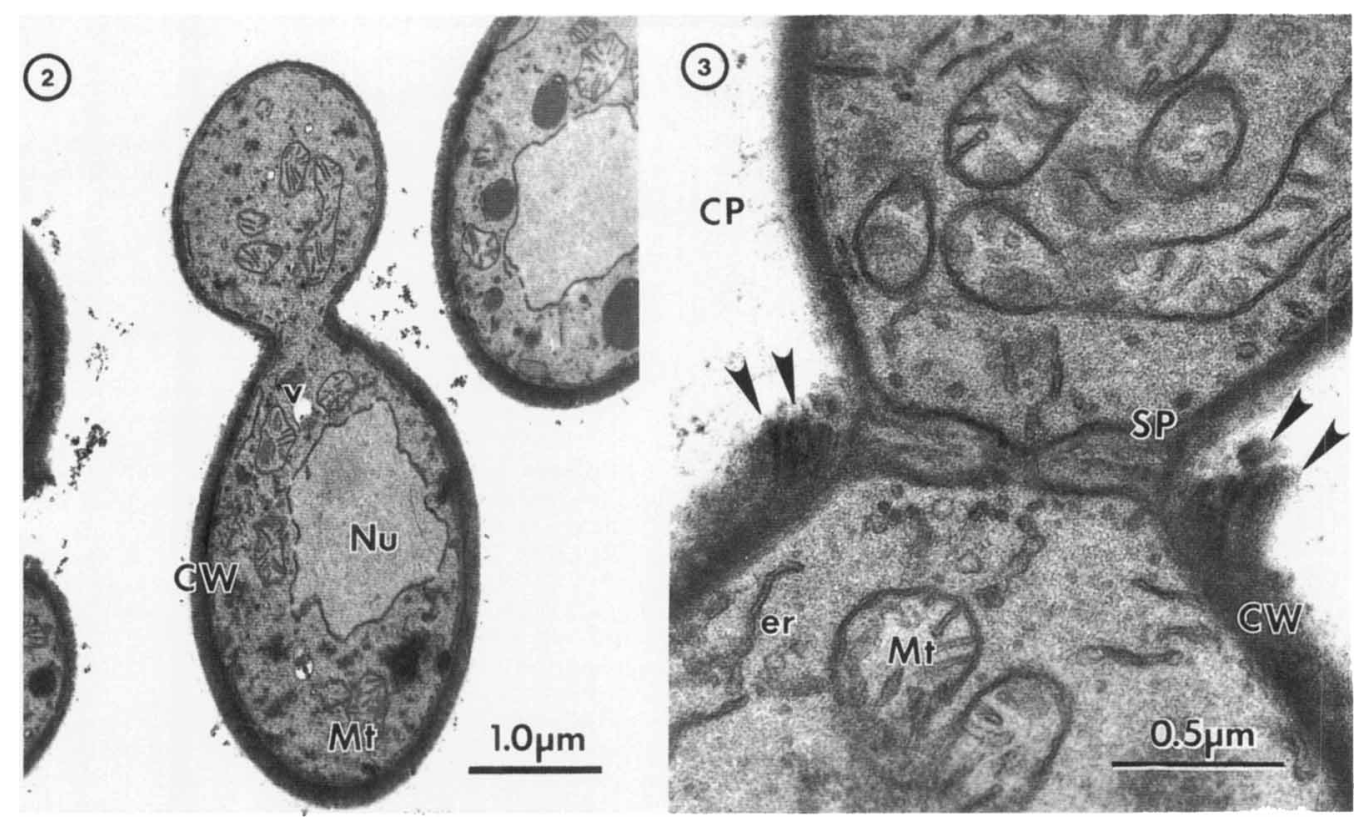

FIG. 2. Transmission electron micrograph of $C$. lupi strain $202 Y 252$ cell with the primary bud still attached. Note the continuation of the whole mother cell wall with that of the bud (holoblastic). CW, Cell wall; Mt, mitochondrion; Nu, nucleus; $v$, vacuole.

FIG. 3. Transmission electron micrograph of $C$. lupi strain $202 Y 252$ showing secondary budding. The bud cell wall is continuous only with the inner mother cell wall layer(s) (enterblastic). The arrow-heads indicate the frayed outer layers making up the bud scar collar. A septum is formed at the level of the frayed collar. CP, Remains of the capsule; CW, cell wall; er, endoplasmic reticulum; Mt, mitochondrion; SP, septum.

mide per $\mathrm{ml}$ and is suppressed by $0.5 \mu \mathrm{g}$ of cycloheximide per ml.

Ubiquinone $\mathrm{CoQ}_{9}$ is produced.

Diazonium blue B: positive.

$\mathrm{G}+\mathrm{C}$ content of nuclear DNA: $53.27 \pm 0.21$ mol\%.

These characters code in the widely used system of Barnett et al. (1) as follows: 1, negative; 2 through 4 , ?; 5, negative; 6 through 11, ?; 12 through 14 , negative; 15 and 16 , positive; 17 and 18 , negative; 19 through 24 , positive; 25 , ?; 26 and 27 , negative; 28 and 29 , positive; 30 through 43 , negative; 44 , positive; 45 , ?; 46 through 48 , negative; 49 , positive; $50, ? ; 51$ through 59 , positive; 60 and $61, ? ; 62$, negative; $63, ? ; 64$, negative; 65 , positive; 66 , negative; 67 , negative; 69 and 70 , positive; 71 through 78 , negative.

\section{DISCUSSION}

Observation of colony color (not red or pink) and determination of assimilation of $\mathbf{L}$-arabinose (positive), galactose (negative), 2-ketogluconate (negative), lactose (negative), and D-mannitol (negative) under conditions (temperature and media) appropriate for $C$. lupi allow presumptive identification of isolates with this species rather than any other yeast species described previously. $C$. lupi is phenotypically most similar to $C$. vishniacii and to biotypes 10,11 , and 16 of that species. $C$. lupi differs from the type strain of $C$. vishniacii by the assimilation of cellobiose, methyl- $\alpha$-D-glucoside, and salicin, by the failure to assimilate $\gamma$-amino butyric acid (type slow), gluconate (type slow) 2-ketogluconate, 5-ketogluconate (type slow), L-rhamnose (type weak), and succinate, by higher optimal and maximal growth temperatures, and in cell size and the ratio of cell width to length (1). C. lupi differs from $C$. vishniacii biotypes 10,11 , and 16 in the following characters: failure to assimilate $\gamma$ amino butyric acid (biotypes 10 and 11, slow), Laspartate (biotypes 10,11 , and 16, slow), 2ketogluconate (biotypes 10,11, and 16, weak), L-rhamnose (biotype 16 , positive), or succinate (biotypes 10 and 11, positive) and lower susceptibility to cycloheximide (biotype 16, suppressed by $0.05 \mu \mathrm{g} / \mathrm{ml}$ ).

The use of the $\mathrm{G}+\mathrm{C}$ content of the nuclear DNA to exclude conspecificity has become a standard procedure in the taxonomy of yeasts known only as anamorphs. A difference of more than $1 \mathrm{~mol} \%$ is considered to preclude signifi- 
cant DNA-DNA homology in yeasts (10); that is, such a difference is associated with a failure to mate with the production of fertile recombinant offspring in teleomorphic strains. This information is based on studies with ascomycetous yeasts and ascoblastomycetes and has yet to be confirmed for the less-well-known basidioblastomycetes. The biotypes assigned here to $C$. lupi show no significant differences in phenotype (14, 15 ) or in $\mathrm{G}+\mathrm{C}$ content (isolate 202Y252, 53.27 \pm $0.21 \mathrm{~mol} \%$; isolate $202 \mathrm{Y} 375,53.30 \pm 0.16 \mathrm{~mol} \%$ ) but differ by at least $1.5 \mathrm{~mol} \%$ from the values determined for other biotypes of $C$. vishniacii. The DNA of the type strain of $C$. vishniacii contains $54.97 \pm 0.16 \mathrm{~mol} \% \mathrm{G}+\mathrm{C}$; biotype 10 (the closest biotype) contains $54.80 \pm 0.19 \mathrm{~mol} \%$ $\mathrm{G}+\mathrm{C}$. DNA-DNA homology is less than $20 \%$ (unpublished data).

Our interest in the taxonomy of these yeasts derives from their importance in analyses of the Antarctic ecosystem. We need genetic measures of relatedness because lack of equivalence of taxonomic levels has been a major problem in the application of theoretical ecology to ecosystems containing both macrobes and microbes. We need (and have attempted to find) easily determined descriptors other than those generally used in yeast identification both because these fail to distinguish recognized species (7) and because we need to identify diversity at subspecific levels. Finally, although there are practical limits to the number of assimilation tests that can be performed, as well as the theoretical objection that habitats may not provide unmixed substrates, extended test series provide a major source of data on resource utilization. Apart from airspora, the closest resources for heterotrophs in the more barren areas of the Dry Valleys of Antarctica are endolithic lichens (Buellia) (5) and cyanobacteria (6). The failure of yeasts belonging to the $C$. vishniacii complex to utilize any commercially available polyols makes it unlikely that these organisms can derive immediate benefit from association with the more common chlorophycean lichens (4).

\section{ACKNOWLEDGMENTS}

This study was supported by research grant NAGW-26 from the National Aeronautics and Space Administration.

We also thank John A. Bantle, Zoology Department, Oklahoma State University, for helpful discussions and for allowing us to rebuild and use his centrifuge, and Sandra Reisbeck,
Electron Microscope Laboratory, for technical assistance with sectioning for electron microscopy.

\section{REPRINT REQUESTS}

Address reprint requests to: Dr. H. S. Vishniac, Department of Microbiology, Oklahoma State University, Stillwater, OK 74074 .

\section{LITERATURE CITED}

1. Baharaeen, S., and H. S. Vishniac. 1981. Budding morphology of a psychrophilic Cryptococcus and related species compared with Leucosporidium scottii. Mycologia 73:618-633.

1a.Barnett, J. A., R. W. Payne, and D. Yarrow. 1979. A guide to identifying and classifying yeasts. Cambridge University Press, Cambridge.

2. Beckman Instruments, Inc. 1975. Prep UV scanner instruction manual. Manual LUV-IM-2. Beckman Instruments, Inc., Fullerton, Calif.

3. Bernardi, G., M. Faures, G. Pipers, and P. P. Slonimski. 1970. Mitochondrial DNAs from respiratory-sufficient and cytoplasmic respiratory-deficient mutants of yeast. $J$. Mol. Biol. 48:23-43.

4. Cooke, R. 1977. The biology of symbiotic fungi. John Wiley \& Sons, Inc., New York.

5. Friedmann, E. I., and A. P. Kibler. 1980. Nitrogen economy of endolithic microbial communities in hot and cold deserts. Microb. Ecol, 6:95-108.

6. Friedmann, E. I., and R. Ocampo. 1976. Endolithic bluegreen algae in the Dry Valleys: primary producers in the Antarctic desert ecosystem. Science 193:1247-1249.

7. Kwon-Chung, K. J. 1976. A new species of Filobasidiella, the sexual state of Cryptococcus neoformans B and $C$ serotypes. Mycologia 68:942-946.

8. Marmur, J. 1961. A procedure for the isolation of DNA from microorganisms. J. Mol. Biol. 3:208-218.

9. Mendonca-Hagler, L. C., and H. J. Phaff. 1975. Deoxyribonucleic acid base composition and DNA:DNA hybrid formation in psychrophobic and related yeasts. Int. J. Syst. Bacteriol. 25:222-229.

10. Price, C. W., G. B. Fuson, and H. J. Phaff. 1978. Genome comparison in yeast systematics: delimitation of species within the genera Schwanniomyces, Saccharomyces, Debaryomyces, and Pichia. Microbiol. Rev. 42:161-193.

11. Schildkraut, C. L., J. Marmur, and P. Doty. 1962. Determination of the base composition of deoxyribonucleic acid from its buoyant density in CsCl. J. Mol. Biol. 4:430433 .

12. Szybalski, W. 1968 . Use of cesium sulfate for equilibrium density gradient centrifugation. Methods Enzymol. 12B:330-360.

13. van der Walt, J. P., and V. K. Hopsu-Havu. 1976. A colour reaction for the differentiation of ascomycetous and hemibasidiomycetous yeasts. Antonie van Leeuwenhoek J. Microbiol. Serol. 42:157-163.

14. Vishniac, H. S., and W. P. Hempfling. 1979. Cryptococcus vishniacii sp. nov., an Antarctic yeast. Int. J. Syst. Bacteriol. 29:153-158.

15. Vishniac, H. S., and W. P. Hempfling. 1979. Evidence of an indigenous microbiota (yeast) in the Dry Valleys of Antarctica. J. Gen. Microbiol. 112:301-314.

16. Yamada, Y., and K. Kondo. 1973. Coenzyme Q system in the classification of the yeast genera Rhodotorula and Cryptococcus, and the yeast-like genera Sporobolomyces and Rhodosporidium. J. Gen. Appl. Microbiol. 19:59-77. 